\title{
The Body Fat Percentage Rather Than the BMI Is Associated with the CD4 Count among HIV Positive Japanese Individuals
}

\author{
Kumiko Shoji ${ }^{1, *}$, Michinori Shirano ${ }^{2}$, Mitsuru Konishi ${ }^{3}$, Yuko Toyoshima ${ }^{4}$, Miyuki Matsumoto ${ }^{5}$, Tetsushi Goto ${ }^{2}$, \\ Yu Kasamatsu ${ }^{2,6}$, Yuji Ichida ${ }^{7}$, Yasuo Kagawa ${ }^{1}$, Terue Kawabata ${ }^{1}$, Hiromitsu Ogata ${ }^{1}$ and Daiki Habu ${ }^{8}$ \\ 1 Faculty of Nutrition, Kagawa Nutrition University, Saitama 350-0288, Japan; kagawa@eiyo.ac.jp (Y.K.) \\ kawabata@eiyo.ac.jp (T.K.); ogata.hiromitsu@eiyo.ac.jp (H.O.) \\ 2 Department of Infectious Disease, Osaka City General Hospital, Osaka 534-0021, Japan; \\ shirano@wonder.ocn.ne.jp (M.S.); gototet@yahoo.co.jp (T.G.); hmorimoto2002@yahoo.co.jp (Y.K.) \\ 3 Center for Health Control, Nara Medical University, Nara 634-8521, Japan; mkonishi@naramed-u.ac.jp \\ 4 Department of Nursing, Osaka City General Hospital, Osaka 534-0021, Japan; yu-toyoshima@osakacity-hp.or.jp \\ $5 \quad$ Kurokawa Clinic, Osaka 557-0031, Japan; ayasuke61720@cap.ocn.ne.jp \\ 6 Department of Infectious Disease, University Hospital, Kyoto Prefectural University of Medicine, \\ Kyoto 602-8566, Japan \\ 7 Department of Pharmacy, Osaka City General Hospital, Osaka 534-0021, Japan; yk.ichida@space.ocn.ne.jp \\ 8 Graduate School of Human Life Science, Osaka City University, Osaka 558-8585, Japan; habu@osaka-cu.ac.jp \\ * Correspondence: shoji.kumiko@eiyo.ac.jp; Tel.: +81-49-282-3705
}

check for

updates

Citation: Shoji, K.; Shirano, M.;

Konishi, M.; Toyoshima, Y.;

Matsumoto, M.; Goto, T.; Kasamatsu,

Y.; Ichida, Y.; Kagawa, Y.; Kawabata,

T.; et al. The Body Fat Percentage

Rather Than the BMI Is Associated

with the CD4 Count among HIV

Positive Japanese Individuals.

Nutrients 2022, 14, 428. https://

doi.org/10.3390/nu14030428

Received: 20 December 2021

Accepted: 12 January 2022

Published: 18 January 2022

Publisher's Note: MDPI stays neutral with regard to jurisdictional claims in published maps and institutional affiliations.

Copyright: (c) 2022 by the authors. Licensee MDPI, Basel, Switzerland. This article is an open access article distributed under the terms and conditions of the Creative Commons Attribution (CC BY) license (https:// creativecommons.org/licenses/by/ $4.0 /)$.

\begin{abstract}
Maintenance of the cluster of differentiation 4 (CD4) positive lymphocyte count (CD4 count) is important for human immunodeficiency virus (HIV) positive individuals. Although a higher body mass index (BMI) is shown to be associated with a higher CD4 count, BMI itself does not reflect body composition. Therefore, we examined the association of body weight, body composition and the CD4 count, and determined the optimal ranges of CD4 count associated factors in Japanese HIV positive individuals. This cross-sectional study included 338 male patients treated with antiretroviral therapy for $\geq 12$ months. Multiple logistic regression analysis was used to identify factors significantly associated with a CD4 count of $\geq 500$ cells $\left(\mathrm{mm}^{3}\right)^{-1}$. The cutoff values of factors for a CD4 $\geq 500$ cells $\left(\mathrm{mm}^{3}\right)^{-1}$ and cardiovascular disease risk were obtained by receiver operating characteristic curves. Age, body fat percentage (BF\%), nadir CD4 count, duration of antiretroviral therapy (ART), years since the HIV-positive diagnosis and cholesterol intake showed significant associations with the CD4 count. The cutoff value of BF\% for a CD4 $\geq 500$ cells $\left(\mathrm{mm}^{3}\right)^{-1}$ and lower cardiovascular disease risk were $\geq 25.1 \%$ and $\leq 25.5 \%$, respectively. The $\mathrm{BF} \%$, but not the $\mathrm{BMI}$, was associated with CD4 count. For the management of HIV positive individuals, $25 \%$ appears to be the optimal BF\% when considering the balance between CD4 count management and cardiovascular disease risk.
\end{abstract}

Keywords: HIV; CD4 count; body fat percentage; cardiovascular disease risk

\section{Introduction}

With the development of antiretroviral therapy (ART), the mortality rate of human immunodeficiency virus (HIV)-positive individuals has drastically improved [1]. In the absence of risk factors, such as comorbid viral hepatitis, drug abuse, and smoking, the life expectancy of HIV-positive individuals is very close to that of HIV-negative individuals [2,3]. It was also shown that the mortality rate did not differ significantly between healthy individuals and HIV-positive men with a CD4 positive lymphocyte count (CD4 count) of $500 / \mathrm{mm}^{3}$ or higher and no risk factors [4]. This indicates that in addition to the HIV RNA levels, which can be controlled relatively well with ART, the control of CD4 count is important for HIV positive individuals.

Recently, there was an increasing number of reports showing that weight and body fat (BF) increase with ART, particularly with integrase strand transfer inhibitors (INSTIs) [5-7]. 
In addition, in areas of the world with abundant food resources and a good health care system, the rates of overweight and obesity are higher than the rates of undernutrition, which was the most important issue before the introduction of ART [8]. There are several reports showing a relationship between body weight and the CD4 count, e.g., a 1-unit increase in the body mass index (BMI) raised the CD4 count by 8.7 cells $\left(\mathrm{mm}^{3}\right)^{-1}$ [9], and a higher BMI was associated with long-term advantages in CD4 count recovery with ART [10]. However, the BMI itself does not reflect body composition [11,12]; it remains unclear whether it is the BF, muscle or body weight that is associated with the CD4 count.

This study examined the associations among body weight, body composition and the CD4 count among Japanese men living with HIV, taking into consideration their nutritional intakes and other lifestyle factors. At the same time, the optimal ranges of the factors associated with the CD4 count were determined for consideration of the balance between CD4 count management and the risk of cardiovascular disease.

\section{Materials and Methods}

\subsection{Study Design and Subjects}

This was a cross-sectional study conducted at two hospitals in Japan between 2014 and 2017. A total of 338 patients were included. Since it was reported that the growth of HIV can be suppressed after 1 year of ART [13], this study was limited to those who had been on ART for at least 12 months. Figure 1 shows the flowchart for subject selection, and 289 patients were included for the final analysis.

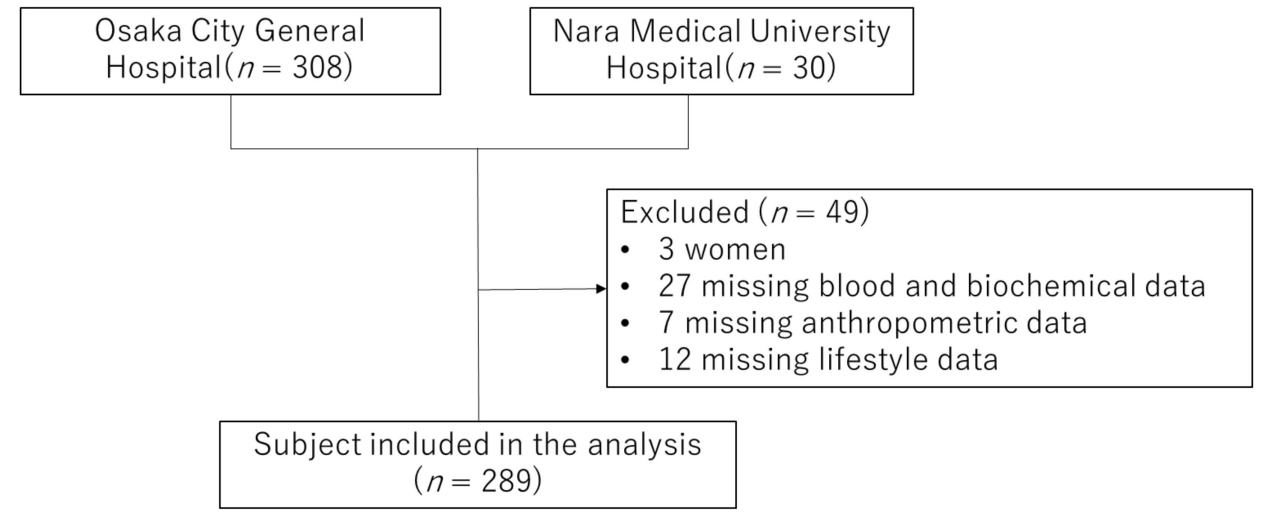

Figure 1. Flow chart for the study subject.

\subsection{Anthropometric Measurement}

All of the anthropometric indices were measured in each patient during one of their outpatient visits. The body weight, $\mathrm{BF}$, muscle mass and $\mathrm{BF}$ percentage $(\mathrm{BF} \%)$ were measured using a bioimpedance method by InBody230 (InBody Japan Inc., Tokyo, Japan).

\subsection{Dietary Intake}

The energy intake, nutritional intake, and the intake of individual food groups were calculated from the frequency of intake of 58 foods commonly consumed by Japanese people using the brief self-administered diet history questionnaire (BDHQ) developed by Sasaki et al. [14,15]. Responses to the questionnaire were requested on the same day of anthropometric measurement. The exclusion criteria for reporting errors on BDHQ were values $<0.5$ times the energy requirement of Physical Activity Level I or $>1.5$ times the energy requirement of Physical Activity Level III for each subject. Energy adjustments were made based on the density method (nutrient intake per $1000 \mathrm{kcal}$ of energy intake).

\subsection{Lifestyle Indices}

Data on the patients' current smoking habit, physical activity level, number of meals consumed per day, amount of sleep and whether or not they could sleep well were obtained from self-administered questionnaires conducted on the same day of anthropometric measurement. 


\subsection{Blood Collection, and Blood and Biochemical Tests}

Patient blood was collected on the day or within 1 week of the anthropometric measurements and dietary and lifestyle survey. Data on the white blood cell count (WBC; cells $\left.\mu \mathrm{L}^{-1}\right)$, lymphocyte percentage (Lym\%), albumin level $\left(\mathrm{g} \mathrm{dL}^{-1}\right)$, total cholesterol level (T-chol; $\mathrm{mg} \mathrm{dL}^{-1}$ ), low-density lipoprotein cholesterol level (LDL-chol; $\mathrm{mg} \mathrm{dL}^{-1}$ ), highdensity lipoprotein cholesterol level (HDL-chol; $\mathrm{mg} \mathrm{dL}^{-1}$ ), triglyceride level (TG; $\mathrm{mg} \mathrm{dL}^{-1}$ ), fasting glucose level $\left(\mathrm{mg} \mathrm{dL}^{-1}\right), \mathrm{CD} 4$ percentage $(\mathrm{CD} 4 \%), \mathrm{CD} 8$ percentage $(\mathrm{CD} 8 \%)$ and HIV-RNA level were collected from the medical charts of the patients. Because the WBC, TLC, CD4 count and CD8 count are highly variable indices, we averaged the data from three different time points (the time of the survey and two previous outpatient visits). Data on the nadir CD4 count, duration of ART, current key drug, number of years since the HIV-positive diagnosis, history of a diagnosis of acquired immunodeficiency syndrome (AIDS) and comorbidities were also collected from the medical charts.

\subsection{Arteriosclerosis-Related Indices}

Blood pressure pulse wave tests were performed on a separate day from the outpatient clinic. The higher value of the left or right side of the branchial-ankle pulse wave velocity (baPWV), which is an index of arterial stiffness [16], was used in the analysis as baPWV max. The Ankle-Branchial Pressure Index (ABI), which is an indicator of arteriosclerosis obliterans [17], was set at the higher value on either the right or left sides. An ABI $\leq 0.9$ is considered to indicate the presence of stenotic lesions in lower limb arteries with a specificity of almost $100 \%$, and an $\mathrm{ABI} \geq 1.4$ is considered to indicate the presence of arterial calcification [18]. Therefore, these criteria were used as the cutoff values for evaluating the baPWV. These data were available for 97 of the 289 subjects in this study.

\subsection{Evaluation of Metabolic Syndrome}

Metabolic syndrome was defined as a waist circumference $\geq 85 \mathrm{~cm}$ (in males) and the presence of two or more of the following: abnormal lipid metabolism (TG $\geq 150 \mathrm{mg} \mathrm{dL}^{-1}$ and/or HDL-chol $<40 \mathrm{mg} \mathrm{dL}^{-1}$ ), hypertension (systolic blood pressure $\geq 130 \mathrm{~mm} \mathrm{Hg}$ and/or diastolic blood pressure $\geq 85 \mathrm{~mm} \mathrm{Hg}$ ) and abnormal glucose metabolism (fasting blood glucose level $\geq 110 \mathrm{mg} \mathrm{dL}^{-1}$ ) [19]. A waist circumference $\geq 85 \mathrm{~cm}$ and the presence of one of the other factors were considered to indicate pre-metabolic syndrome.

\subsection{Statistical Analysis}

The normality of each index was confirmed based on the skewness (between -0.5 to $0.5)$ or $p>0.05$ tested by Shapiro-Wilk's W test. The Mann-Whitney U test, Chi-squared test and Fisher's exact test were used to compare the differences between groups. For multiple logistic regression analysis, factors that showed a statistically significant difference between the subjects with a CD4 count of $\geq 500$ cells $\left(\mathrm{mm}^{3}\right)^{-1}$ and those with a CD4 count of $<500$ cells $\left(\mathrm{mm}^{3}\right)^{-1}$ were used. A stepwise method (variable increase by the likelihood ratio) was used. IBM SPSS version 22.0 software (SPSS Inc., Chicago, IL, USA) was used for the analysis.

\subsection{Ethical Considerations}

Informed consent was obtained from all subjects involved in the study. This study was conducted with the approval of the Ethics Committee of the Osaka City General Medical Center (ID: 1312063) and Nara Medical University Hospital (ID: 1200).

\section{Results}

The patient characteristics are shown in Table 1 . The CD4 $\geq 500$ cells $\left(\mathrm{mm}^{3}\right)^{-1}$ group was significantly younger and had a higher BMI than the CD4 $<500$ cells $\left(\mathrm{mm}^{3}\right)^{-1}$ group. In terms of HIV-related indices, the WBC, Lym\%, TLC, CD4 count, CD8 count, CD4/CD8 ratio and nadir CD4 count were all significantly higher. The rate of having a history of an AIDS diagnosis was significantly lower, and the duration since the HIV-positive diagnosis 
and the duration of ART were significantly longer in the CD4 $\geq 500$ cells $\left(\mathrm{mm}^{3}\right)^{-1}$ group than in the CD4 $<500$ cells $\left(\mathrm{mm}^{3}\right)^{-1}$ group. The use of INSTIs was greater than $60 \%$ in both groups.

Table 1. Characteristics of the total patients and separated by CD4 count 500 cells $\left(\mathrm{mm}^{3}\right)^{-1}$.

\begin{tabular}{|c|c|c|c|c|c|c|c|}
\hline & \multicolumn{2}{|c|}{ Total $(n=289)$} & \multicolumn{2}{|c|}{ CD4 $\geq 500$ Cells $\left(\mathrm{mm}^{3}\right)^{-1}(n=160)$} & \multicolumn{2}{|c|}{ CD4 < 500 Cells $\left(\mathrm{mm}^{3}\right)^{-1}(n=129)$} & \multirow[b]{2}{*}{$p^{*}$} \\
\hline & Median & $\begin{array}{l}\text { (25th, } 75 \text { th } \\
\text { Percentile) or }(\%)\end{array}$ & Median & $\begin{array}{l}\quad(25 \text { th, } 75 \text { th } \\
\text { Percentile) or }(\%)\end{array}$ & Median & $\begin{array}{c}\text { (25th, } 75 \text { th } \\
\text { Percentile) or }(\%)\end{array}$ & \\
\hline Age (years old) & 45 & $(39,54)$ & 44 & $(37,51)$ & 47 & $(40,59)$ & 0.011 \\
\hline Height $(\mathrm{cm})$ & 170.0 & $(166.0,173.3)$ & 170.0 & $(165.3,174.0)$ & 170.0 & $(166.0,173.0)$ & 0.802 \\
\hline Weight (kg) & 67.2 & $(60.0,75.3)$ & 68.3 & $(61.0,76.7)$ & 65.4 & $(58.4,72.9)$ & 0.029 \\
\hline $\mathrm{BMI}\left(\mathrm{kg}\left(\mathrm{m}^{2}\right)^{-1}\right)$ & 23.3 & $(21.0,25.8)$ & 23.7 & $(21.4,26.5)$ & 22.7 & $(20.6,25.0)$ & 0.010 \\
\hline WBC & 5566 & $(4847,6612)$ & 6088 & $(5316,7285)$ & 5143 & $(4575,5917)$ & $<0.0001$ \\
\hline Lymp (\%) & 34.6 & $(29.4,39.7)$ & 36.9 & $(31.1,41.0)$ & 31.3 & $(26.3,37.0)$ & $<0.0001$ \\
\hline TLC $\left(\right.$ cells $\left.\left(\mathrm{mm}^{3}\right)^{-1}\right)$ & 1880 & $(1491,2408)$ & 2242 & $(1787,2618)$ & 1554 & $(1283,1849)$ & $<0.0001$ \\
\hline $\begin{array}{c}\text { CD4 count } \\
\left.\left(\text { cells }\left(\mathrm{mm}^{3}\right)^{-1}\right)\right)\end{array}$ & 532 & $(397,667)$ & 656 & $(578,764)$ & 378 & $(296,449)$ & $<0.0001$ \\
\hline $\begin{array}{c}\text { CD8 count } \\
\left.\left(\text { cells }\left(\mathrm{mm}^{3}\right)^{-1}\right)\right)\end{array}$ & 830 & $(632,1132)$ & 939 & $(699,1210)$ & 720 & $(533,939)$ & $<0.0001$ \\
\hline CD4/CD8 ratio & 0.64 & $(0.46,0.86)$ & 0.74 & $(0.57,0.97)$ & 0.50 & $(0.35,0.67)$ & $<0.0001$ \\
\hline $\begin{array}{l}\text { Nadir CD4 count } \\
\left.\left(\text { cells }\left(\mathrm{mm}^{3}\right)^{-1}\right)\right)\end{array}$ & 133 & $(47,213)$ & 175 & $(100,254)$ & 71 & $(28,140)$ & $<0.0001$ \\
\hline $\begin{array}{l}\text { HIV-RNA } \geq 20 \\
\left(\text { copies } \mathrm{mL}^{-1}\right)\end{array}$ & 6 & $(2.1)$ & 3 & $(1.9)$ & 3 & $(2.3)$ & 0.552 \\
\hline History of AIDS diagnosis & 103 & $(35.6)$ & 41 & $(25.6)$ & 62 & $(48.1)$ & $<0.0001$ \\
\hline $\begin{array}{c}\text { Duration since HIV } \\
\text { diagnosis (years) }\end{array}$ & 8 & $(4,11)$ & 8 & $(5,12)$ & 6 & $(3,11)$ & 0.001 \\
\hline Duration of ART (months) & 65 & $(35,108)$ & 68.5 & $(41,118)$ & 58 & $(28,103)$ & 0.033 \\
\hline Key drug & & & & & & & 0.196 \\
\hline NNRTIs & 45 & $(15.6)$ & 26 & $(16.3)$ & 19 & $(14.7)$ & \\
\hline PIs & 58 & $(20.1)$ & 26 & (16.3) & 32 & $(24.8)$ & \\
\hline INSTIs & 186 & $(64.4)$ & 108 & $(67.5)$ & 78 & $(60.5)$ & \\
\hline \multicolumn{8}{|l|}{ Comorbidities } \\
\hline Diabetes & 29 & $(10.1)$ & 14 & $(8.8)$ & 15 & $(11.7)$ & 0.405 \\
\hline HTN & 46 & $(16.0)$ & 24 & $(15.0)$ & 22 & $(17.2)$ & 0.615 \\
\hline Hyperlipidemia & 55 & (19.1) & 37 & $(23.1)$ & 18 & $(14.1)$ & 0.052 \\
\hline Fatty liver & 28 & $(9.7)$ & 20 & (12.5) & 8 & $(6.3)$ & 0.075 \\
\hline Virus hepatitis & 75 & (26.0) & 33 & $(20.6)$ & 42 & $(32.6)$ & 0.021 \\
\hline Metabolic syndrome & 90 & $(30.1)$ & 53 & $(33.1)$ & 37 & $(28.7)$ & 0.445 \\
\hline Pre metabolic syndrome & 38 & (13.1) & 23 & (14.4) & 15 & (11.6) & 0.600 \\
\hline
\end{tabular}

$p^{*}:$ CD4 $>500$ cells $\left(\mathrm{mm}^{3}\right)^{-1}$ vs. CD4 $<500$ cells $\left(\mathrm{mm}^{3}\right)^{-1} ;$ Mann-Whitney $U$ test for continuous variables, $x 2$ test or Fisher's exact test for other variables Abbreviations and symbol: BMI, body mass index; WBC, white blood cell; Lymp, lymphocyte; TLC, total lymphocyte count; CD4, CD4 positive lymphocyte; CD8, CD8 positive lymphocyte; ART, Antiretroviral therapy; NNRTIs, Non-nucleoside reverse transcriptase inhibitors; PI, protease inhibitors INSTI, Integrase strand transfer inhibitors; HTN, hypertension.

The blood biochemical and anthropometry measures are shown in Supplementary Table S1. The nutrient and food group intakes are shown in Supplementary Tables S2 and S3, respectively. Data on the other lifestyle factors are shown in Supplementary Table S4.

For the indices that showed a statistically significant difference between the CD4 $\geq 500$ cells $\left(\mathrm{mm}^{3}\right)^{-1}$ and CD4 $<500$ cells $\left(\mathrm{mm}^{3}\right)^{-1}$ groups (Table 1 and Supplementary Tables S1-S4), the cutoff values for discriminating between the CD4 $\geq 500$ cells $\left(\mathrm{mm}^{3}\right)^{-1}$ and CD4 $<500$ cells $\left(\mathrm{mm}^{3}\right)^{-1}$ groups were determined from the receiver operating characteristic

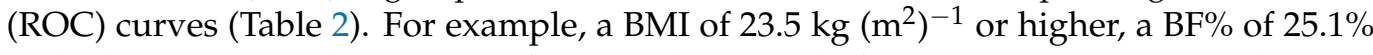
or higher, 28.5 months or more of ART and a period of 5.5 years or more since the HIVpositive diagnosis were considered to be the cutoff values for discriminating between the two groups.

Based on the cutoff values obtained from the ROC curves, each index was transformed into a binary variable, and multiple logistic regression analysis was performed (Table 3). Factors that were significantly associated with a CD4 count of $\geq 500$ cells $\left(\mathrm{mm}^{3}\right)^{-1}$ included the age $(\leq 45.5$ years $), \mathrm{BF} \%(\geq 25.1 \%)$, nadir CD4 count $\left(\geq 137.5\right.$ cells $\left.\left(\mathrm{mm}^{3}\right)^{-1}\right)$, duration of 
ART ( $\geq 28.5$ months), years since the HIV-positive diagnosis ( $\geq 5.5$ years) and cholesterol intake $\left(\leq 265.3 \mathrm{mg} 1000 \mathrm{kcal}^{-1}\right)$.

Table 2. Cutoff values for CD $4 \geq 500$ cells $\left(\mathrm{mm}^{3}\right)^{-1}$ by ROC curve.

\begin{tabular}{|c|c|c|c|}
\hline & AUC & $p$ & Cutoff Value \\
\hline Age (years old) & 0.411 & 0.011 & $\leq 45.5$ \\
\hline $\mathrm{BMI}\left(\mathrm{kg}\left(\mathrm{m}^{2}\right)^{-1}\right)$ & 0.598 & 0.005 & $\geq 23.5$ \\
\hline Waist circumference $(\mathrm{cm})$ & 0.58 & 0.024 & $\geq 87.1$ \\
\hline $\mathrm{BF} \%$ & 0.591 & 0.01 & $\geq 25.1$ \\
\hline $\operatorname{SMI}\left(\mathrm{kg}\left(\mathrm{m}^{2}\right)^{-1}\right)$ & 0.585 & 0.016 & $\geq 7.7$ \\
\hline $\mathrm{Alb}\left(\mathrm{g} \mathrm{dL}^{-1}\right)$ & 0.583 & 0.018 & $\geq 4.25$ \\
\hline LDL-chol (mg dL $\left.{ }^{-1}\right)$ & 0.589 & 0.011 & $\geq 130.5$ \\
\hline non-HDL $\left(\mathrm{mg} \mathrm{dL}^{-1}\right)$ & 0.572 & 0.041 & $\geq 152.3$ \\
\hline Nadir CD4 count (cells $\left.\left(\mathrm{mm}^{3}\right)^{-1}\right)$ & 0.74 & $<0.0001$ & $\geq 137.5$ \\
\hline Duration of ART (months) & 0.573 & 0.04 & $\geq 28.5$ \\
\hline Duration since HIV diagnosis (years) & 0.621 & 0.001 & $\geq 5.5$ \\
\hline NPC-N ratio & 0.577 & 0.03 & $\geq 134$ \\
\hline Calcium intake (mg $\left.1000 \mathrm{kcal}^{-1}\right)$ & 0.424 & 0.032 & $\leq 167.8$ \\
\hline Potassium intake (mg $\left.1000 \mathrm{kcal}^{-1}\right)$ & 0.424 & 0.03 & $\leq 601.9$ \\
\hline Zinc intake $\left(\mathrm{mg} 1000 \mathrm{kcal}^{-1}\right)$ & 0.423 & 0.028 & $\leq 4.44$ \\
\hline Pantothenic acid intake (mg $\left.1000 \mathrm{kcal}^{-1}\right)$ & 0.429 & 0.043 & $\leq 3.47$ \\
\hline Cholesterol intake $\left(\mathrm{mg} 1000 \mathrm{kcal}^{-1}\right)$ & 0.427 & 0.04 & $\leq 265.3$ \\
\hline Weight of beans intake (mg $\left.1000 \mathrm{kcal}^{-1}\right)$ & 0.377 & $<0.0001$ & $\leq 16.4$ \\
\hline
\end{tabular}

Abbreviations and symbol: AUC, area under the curve; BMI, body mass index; $\mathrm{BF} \%$, body fat percentage; SMI, skeletal muscle mass index; Alb, albumin; LDL-chol, low-density lipoprotein cholesterol; nonHDL, non-high-density lipoprotein cholesterol; CD4, CD4 positive lymphocyte; ART, Antiretroviral therapy; NPC-N ratio, non-protein calorie-nitrogen ratio.

Table 3. Univariate and multivariate logistic regression analysis for CD4 $\geq 500$ cells $\left(\mathrm{mm}^{3}\right)^{-1}$.

\begin{tabular}{|c|c|c|c|c|c|c|}
\hline & \multicolumn{3}{|c|}{ Univariate } & \multicolumn{3}{|c|}{ Multivariate } \\
\hline & OR & $95 \% \mathrm{CI}$ & $p$ & OR & $95 \%$ CI & $p$ \\
\hline Age $\leq 45.5$ & 2.20 & $(1.35,3.59)$ & 0.002 & 2.62 & $(1.30,5.27)$ & 0.007 \\
\hline $\mathrm{BMI} \geq 23 . \overline{5} \mathrm{~kg}\left(\mathrm{~m}^{2}\right)^{-1}$ & 1.98 & $(1.21,3.23)$ & 0.007 & & & \\
\hline Waist circumference $\geq 87.1 \mathrm{~cm}$ & 2.09 & $(1.27,3.46)$ & 0.004 & & & \\
\hline $\mathrm{BF} \% \geq 25.1 \%$ & 2.04 & $(1.24,3.36)$ & 0.005 & 3.43 & $(1.71,6.88)$ & 0.001 \\
\hline $\mathrm{SMI} \geq 7 . \overline{\mathrm{kg}}\left(\mathrm{m}^{2}\right)^{-1}$ & 1.91 & $(1.16,3.15)$ & 0.011 & & & \\
\hline $\mathrm{Alb} \geq 4.25 \mathrm{~g} \mathrm{dL}^{-1}$ & 2.07 & $(1.25,3.44)$ & 0.005 & & & \\
\hline LDL-chol $\geq 130.5 \mathrm{mg} \mathrm{dL}^{-1}$ & 2.02 & $(1.15,3.55)$ & 0.014 & & & \\
\hline non-HDL $\geq 152.3 \mathrm{mg} \mathrm{dL}-1$ & 2.08 & $(1.25,3.45)$ & 0.005 & & & \\
\hline Nadir CD4 count $\geq 137.5\left(\mathrm{~mm}^{3}\right)^{-1}$ & 6.82 & $(3.97,11.73)$ & $<0.0001$ & 6.94 & $(3.50,13.75)$ & $<0.0001$ \\
\hline Duration of ART $\geq 28.5$ months & 2.93 & $(1.52,5.66)$ & 0.001 & 2.80 & $(1.04,7.50)$ & 0.041 \\
\hline Duration since HIV diagnosis $\geq 5.5$ years & 2.89 & $(1.73,4.81)$ & $<0.0001$ & 5.06 & $(2.35,10.90)$ & $<0.0001$ \\
\hline NPC-N ratio $\geq 134$ & 2.62 & $(1.50,4.57)$ & 0.001 & & & \\
\hline Calcium intake $\leq 167.8 \mathrm{mg} 1000 \mathrm{kcal}^{-1}$ & 2.21 & $(1.18,4.15)$ & 0.014 & & & \\
\hline Potassium intake $\leq 601.9 \mathrm{mg} 1000 \mathrm{kcal}^{-1}$ & 2.90 & $(1.61,5.22)$ & $<0.0001$ & & & \\
\hline Zinc intake $\leq \overline{4} .44 \mathrm{mg} 1000 \mathrm{kcal}^{-1}$ & 2.84 & $(1.62,4.97)$ & $<0.0001$ & & & \\
\hline Pantothenic acid intake $\leq 3.47 \mathrm{mg} 1000 \mathrm{kcal}^{-1}$ & 2.80 & $(1.64,4.78)$ & $<0.0001$ & & & \\
\hline Cholesterol intake $\leq 265.3 \mathrm{mg} 1000 \mathrm{kcal}^{-1}$ & 3.38 & $(1.63,6.97)$ & 0.001 & 3.37 & $(1.23,9.18)$ & 0.018 \\
\hline Pulses intake $\leq \overline{16} .35 \mathrm{mg} 1000 \mathrm{kcal}^{-1}$ & 2.41 & $(1.47,3.95)$ & $<0.0001$ & & & \\
\hline No history of AIDS diagnosis & 0.40 & $(0.24,0.66)$ & $<0.0001$ & & & \\
\hline No diagnosis of virus hepatitis & 0.61 & $(0.35,1.06)$ & 0.078 & 0.39 & $(0.19,0.82)$ & 0.013 \\
\hline No current smoking habit & 2.09 & $(1.26,3.49)$ & 0.005 & & & \\
\hline Meals per day $\geq 3$ times & 0.53 & $(0.32,0.88)$ & 0.014 & & & \\
\hline
\end{tabular}

Abbreviations and symbol: BMI, body mass index; BF\%, body fat percentage; SMI, skeletal muscle mass index Alb, albumin; LDL-chol, low-density lipoprotein cholesterol; non-HDL, non-high-density lipoprotein cholesterol; CD4, CD4 positive lymphocyte; ART, Antiretroviral therapy; NPC-N ratio, non-protein calorie-nitrogen ratio. 
Since metabolic syndrome is a risk factor for atherosclerosis and cardiovascular disease, the cutoff values of $\mathrm{BF} \%$ for metabolic syndrome and pre-metabolic syndrome were calculated using the ROC curves; the cutoff values were $25.5 \%$ for metabolic syndrome and $23.4 \%$ for pre-metabolic syndrome (Table 4 ). As surrogate markers for the risk of developing cardiovascular disease, we also determined from the ROC curves the cutoff values of $\mathrm{BF} \%$ for a baPWV $\geq 1800 \mathrm{~cm} \mathrm{~s}^{-1}$, which corresponds to a high risk on the Framingham risk score, and for a baPWV $\geq 1400 \mathrm{~cm} \mathrm{~s}^{-1}$, which corresponds to a moderate risk on the Framingham risk score; the cutoff values were $25.8 \%$ for a baPWV $\geq 1800 \mathrm{~cm} \mathrm{~s}^{-1}$ and $24.0 \%$ for a baPWV $\geq 1400 \mathrm{~cm} \mathrm{~s}^{-1}$.

Table 4. Cutoff values of body fat percentage for arteriosclerosis related indices.

\begin{tabular}{cccc}
\hline & AUC & $p$ & BF \% Cutoff Values \\
\hline $\begin{array}{c}\text { Metabolic syndrome } \\
\text { Metabolic syndrome and }\end{array}$ & 0.800 & $<0.0001$ & $25.5 \%$ \\
preliminary metabolic syndrome & 0.837 & $<0.0001$ & $23.4 \%$ \\
baPWV $\geq 1800 \mathrm{~cm} \mathrm{~s}^{-1}$ & 0.647 & 0.083 & $25.8 \%$ \\
baPWV $\geq 1400 \mathrm{~cm} \mathrm{~s}^{-1}$ & 0.659 & 0.011 & $24.0 \%$ \\
\hline
\end{tabular}

Abbreviations and symbol: AUC, area under the curve; $\mathrm{BF} \%$, body fat percentage; baPWV, branchial-ankle pulse wave velocity.

\section{Discussion}

In this study, the age, $\mathrm{BF} \%$, nadir CD4 count, duration of ART, years since the HIVpositive diagnosis and cholesterol intake showed a significant association with the CD4 count. The cutoff value of $\mathrm{BF} \%$ for a CD4 count of $\geq 500$ cells $\left(\mathrm{mm}^{3}\right)^{-1}$ was $25.1 \%$ and over. The cutoff value of $\mathrm{BF} \%$ for the lower risk of cardiovascular disease was $25.5 \%$ and lower. This suggests that $25 \%$ is the optimal BF\% when considering the balance between CD4 count management and cardiovascular disease risk.

Multivariate analysis showed that an age $\leq 45.5$ years, nadir CD4 count of $\geq 137.5$ cells $\left(\mathrm{mm}^{3}\right)^{-1}$ and $\geq 28.5$ months of ART were significant factors for a CD4 count of $\geq 500$ cells $\left(\mathrm{mm}^{3}\right)^{-1}$. Montarroyos et al. reported that with ART, HIV-positive individuals $>40$ years of age showed a significantly smaller elevation in the CD4 count when compared to those $\leq 40$ years of age [20]. Other studies also reported that age was independently associated with CD4 count recovery [21], and that older individuals took more time than younger individuals to recover the CD4 count after the initiation of ART [22]. Aging lowers a person's adaptive immune system, making it harder for older patients to reach a CD4 count of 500 cells $\left(\mathrm{mm}^{3}\right)^{-1}$. Lifson et al. reported that when ART was initiated at a nadir CD4 count of 125 cells $\left(\mathrm{mm}^{3}\right)^{-1}$, it took about 5 years on average to reach a CD4 count of 500 cells $\left(\mathrm{mm}^{3}\right)^{-1}$, and at a nadir CD4 count of 200 to 350 cells $\left(\mathrm{mm}^{3}\right)^{-1}$, it took about 1.5 years for the CD4 count to reach 500 cells $\left(\mathrm{mm}^{3}\right)^{-1}$ [23]. A lower nadir CD4 count means that there is more damage to CD4 T cells before ART initiation, and the results of the present study also support the notion that starting ART earlier leads to higher CD4 counts.

A notable new finding of this study was that a $\mathrm{BF} \%$ of $25.1 \%$ or more was an independent factor for a CD4 count of $\geq 500$ cells $\left(\mathrm{mm}^{3}\right)^{-1}$. There are several reports on the association between BMI and the CD4 count. The rate of CD4 count recovery was high after the initiation of ART in individuals with a pre-treatment BMI of $25 \mathrm{~kg}\left(\mathrm{~m}^{2}\right)^{-1}$ or more [24,25]. In a cross-sectional study, a BMI $\geq 25 \mathrm{~kg}\left(\mathrm{~m}^{2}\right)^{-1}$ was associated with significantly higher CD4 counts [9]. Although the mechanism of the relationship between the BMI and CD4 count remains unclear, leptin has been suggested to be involved. Leptin is an adipocytokine, and its concentration in blood is greatly influenced by increases in BF mass. Leptin promotes the maturation of $\mathrm{T}$ cells from the thymus and prolongs the lifespan of T cells by slowing the rate of apoptosis [26]. Furthermore, leptin regulates the differentiation of CD4 and CD8 double-negative cells into CD4 and CD8 double-positive cells, and CD4 and CD8 double-positive cells into CD4-positive CD8-negative cells both in vitro and in vivo [27]. In the present study, both the $\mathrm{BMI}$ and $\mathrm{BF} \%$ were entered into the 
multivariate analysis, and the $\mathrm{BF} \%$, but not the $\mathrm{BMI}$, was extracted as a significant factor. This result provides strong support for the association between adipocytes, leptin and the CD4 count.

Although the multivariate analysis showed that a $\mathrm{BF} \%$ of $25.1 \%$ or higher is desirable for a CD4 count of $\geq 500$ cells $\left(\mathrm{mm}^{3}\right)^{-1}$, an increase in the $\mathrm{BF} \%$ is reported to be associated with cardiovascular disease risk [12]. The increase in cardiovascular disease risk cannot be ignored in HIV-positive individuals since they have chronic inflammation due to the human retrovirus [28], and it is reported to increase the risk for cardiovascular disease $[29,30]$. In this study, the cutoff value of the $\mathrm{BF} \%$ was $25 \%$ to $26 \%$ for both metabolic syndrome and the baPWV. Hiroshige et al. reported that the average BF\% of 267 working Japanese males who were negative for HIV was 22.2\% [31]; our cutoff values for CD4 count management and cardiovascular disease risk (25.1\% and 25.5\%, respectively) were both slightly higher. In addition, Asians tend to have a higher BF\% than Caucasians at the same BMI value [32,33]. Thus, the body composition is the important factor for the Japanese population. Moreover, HIV individuals with ART present lipodystrophy (lipoatrophy/lipohypertrophy). Soares et al. reported that anthropometric measurement is needed to evaluate the nutritional status of HIV individuals [34]. This also supports that body composition measurement is essential for HIV individuals.

This study has a few limitations. This study included only male patients, and thus, the results cannot be applied to female HIV patients. However, according to the AIDS Outbreak Trends Survey, more than $90 \%$ of the HIV cases in Japan are male. In addition, new HIV infections are generally reported in patients in their $20 \mathrm{~s}$ to $40 \mathrm{~s}$, and new AIDS cases are generally reported in patients in their $40 \mathrm{~s}$ [35]. Therefore, the population of this study is considered closely to reflect the distribution of the population of people living with HIV in Japan. The cross-sectional nature of the data is another limitation of this study. Of the factors included in the analysis, the nadir CD4 count and the duration of ART were retrospectively collected information taken from the data records of the patients. This made it possible to state a causal relationship even with the cross-sectional data. However, the other factors extracted by multivariate analysis can only be described as relevant in this study. In the future, a prospective cohort study should be performed to examine whether the $\mathrm{BF} \%$ affects the control of the $\mathrm{CD} 4$ count.

\section{Conclusions}

This study showed that the $\mathrm{BF} \%$, and not the BMI, was associated with the CD4 count, and that a $\mathrm{BF} \%$ of $25.1 \%$ or more may be advantageous for maintaining the CD4 count in HIV-positive individuals. However, a BF\% of $25.5 \%$ or more may increase the risk of coronary artery disease. Thus, for the management of HIV-positive individuals, regular measurements of body composition are recommended.

Supplementary Materials: The following supporting information can be downloaded at: https: / / www.mdpi.com/article/10.3390/nu14030428/s1, Table S1: Blood biochemical and anthropometry values-Total subjects and separated by CD4 count 500 cells $\left(\mathrm{mm}^{3}\right)^{-1}$, Table S2: Energy adjusted nutrient intakes-Total subjects and separated by CD4 count 500 cells $\left(\mathrm{mm}^{3}\right)^{-1}$, Table S3: Energy adjusted food group intakes-Total subjects and separated by CD4 count 500 cells $\left(\mathrm{mm}^{3}\right)^{-1}$, Table S4: Lifestyle factors-Total subjects and separated by CD4 count 500 cells $\left(\mathrm{mm}^{3}\right)^{-1}$.

Author Contributions: Conceptualization and methodology, K.S., D.H. and M.S.; validation, D.H., M.S., M.K., T.G. and Y.K. (Yu Kasamatsu); formal analysis, K.S. and H.O.; investigation, K.S., D.H., M.S., M.K., Y.T., M.M., T.G. and Y.K. (Yu Kasamatsu); resources, D.H., M.S., M.K., T.G. and Y.K. (Yu Kasamatsu); data curation, K.S.; writing-original draft preparation, K.S.; writing-review and editing, K.S., D.H., T.K., M.S., M.K., Y.T., M.M., T.G., Y.K. (Yu Kasamatsu), Y.I., Y.K. (Yasuo Kagawa) and H.O.; visualization, K.S.; supervision, D.H.; project administration, D.H.; funding acquisition, K.S. and D.H. All authors have read and agreed to the published version of the manuscript.

Funding: This research received no external funding. 
Institutional Review Board Statement: This study was conducted with the approval of the Ethics Committee of the Osaka City General Medical Center (ID: 1312063, date of approval: 28 January 2014) and Nara Medical University Hospital (ID: 1200, date of approval: 27 October 2016).

Informed Consent Statement: Informed consent was obtained from all subjects involved in the study. Data Availability Statement: Not applicable.

Acknowledgments: We thank the participants in this study. We also express huge appreciation to the members of the Laboratory of medical nutrition at Osaka City University.

Conflicts of Interest: The authors declare no conflict of interest.

\section{References}

1. Antiretroviral Therapy Cohort Collaboration. Survival of HIV-positive patients starting antiretroviral therapy between 1996 and 2013, A collaborative analysis of cohort studies. Lancet HIV 2017, 4, 349-356. [CrossRef]

2. Obel, N.; Omland, L.H.; Kronborg, G.; Larsen, C.S.; Pedersen, C.; Pedersen, G.; Sorensen, H.T.; Gerstoft, J. Impact of non-HIV and HIV risk factors on survival in HIV-infected patients on HAART: A population-based nationwide cohort study. PLoS ONE 2011, 6, e22698. [CrossRef]

3. Marcus, J.L.; Chao, C.R.; Leyden, W.A.; Xu, L.; Quesenberry, C.P., Jr.; Klein, D.B.; Towner, W.J.; Horberg, M.A.; Silverberg, M.J. Narrowing the Gap in Life Expectancy between HIV-Infected and HIV-Uninfected Individuals with Access to Care. J. Acquir. Immune Defic. Syndr. 2016, 73, 39-46. [CrossRef] [PubMed]

4. $\quad$ Lewden, C.; Bouteloup, V.; De Wit, S.; Sabin, C.; Mocroft, A.; Wasmuth, J.C.; van Sighem, A.; Kirk, O.; Obel, N.; Panos, G.; et al. All-cause mortality in treated HIV-infected adults with CD $>/=500 / \mathrm{mm}^{3}$ compared with the general population: Evidence from a large European observational cohort collaboration. Int. J. Epidemiol. 2012, 41, 433-445. [CrossRef]

5. Vizcarra, P.; Vivancos, M.J.; Pérez-Elías, M.J.; Moreno, A.; Casado, J.L. Weight gain in people living with HIV switched to dual therapy: Changes in body fat mass. AIDS 2020, 34, 155-157. [CrossRef]

6. Sax, P.E.; Erlandson, K.M.; Lake, J.E.; McComsey, G.A.; Orkin, C.; Esser, S.; Brown, T.T.; Rockstroh, J.K.; Wei, X.; Carter, C.C.; et al. Weight Gain Following Initiation of Antiretroviral Therapy: Risk Factors in Randomized Comparative Clinical Trials. Clin. Infect Dis. 2020, 71, 1379-1389. [CrossRef]

7. Venter, W.D.F.; Moorhouse, M.; Sokhela, S.; Fairlie, L.; Mashabane, N.; Masenya, M.; Serenata, C.; Akpomiemie, G.; Qavi, A.; Chandiwana, N.; et al. Dolutegravir plus Two Different Prodrugs of Tenofovir to Treat HIV. N. Engl. J. Med. 2019, 381, 803-815. [CrossRef]

8. Amorosa, V.; Synnestvedt, M.; Gross, R.; Friedman, H.; MacGregor, R.R.; Gudonis, D.; Frank, I.; Tebas, P. A tale of 2 epidemics: The intersection between obesity and HIV infection in Philadelphia. J. Acquir. Immune Defic. Syndr. 2005, 39, 557-561.

9. Blashill, A.J.; Mayer, K.H.; Crane, H.M.; Grasso, C.; Safren, S.A. Body mass index, immune status, and virological control in HIV-infected men who have sex with men. J. Int. Assoc. Provid. AIDS Care. 2013, 12, 319-324. [CrossRef] [PubMed]

10. Koethe, J.R.; Jenkins, C.A.; Lau, B.; Shepherd, B.E.; Wester, W.; Rebeiro, P.F.; Silverberg, M.J.; Thorne, J.E.; Gill, J.; Mayor, A.M.; et al. Higher Time-Updated Body Mass Index: Association with Improved CD4+ Cell Recovery on HIV Treatment. J. Acquir. Immune Defic. Syndr. 2016, 73, 197-204. [CrossRef] [PubMed]

11. Iyengar, N.M.; Arthur, R.; Manson, J.E.; Chlebowski, R.T.; Kroenke, C.H.; Peterson, L.; Cheng, T.D.; Feliciano, E.C.; Lane, D.; Luo, J.; et al. Association of Body Fat and Risk of Breast Cancer in Postmenopausal Women with Normal Body Mass Index: A Secondary Analysis of a Randomized Clinical Trial and Observational Study. JAMA Oncol. 2019, 5, 155-163. [CrossRef] [PubMed]

12. Si, S.; Tewara, M.A.; Ji, X.; Wang, Y.; Liu, Y.; Dai, X.; Wang, Z.; Xue, F. Body surface area, height, and body fat percentage as more sensitive risk factors of cancer and cardiovascular disease. Cancer Med. 2020, 9, 4433-4446. [CrossRef] [PubMed]

13. Simonetti, F.R.; Kearney, M.F. Review: Influence of ART on HIV genetics. Curr. Opin. HIV AIDS 2015, 10, 49-54. [CrossRef] [PubMed]

14. Kobayashi, S.; Honda, S.; Murakami, K.; Sasaki, S.; Okubo, H.; Hirota, N.; Notsu, A.; Fukui, M.; Date, C. Both comprehensive and brief self-administered diet history questionnaires satisfactorily rank nutrient intakes in Japanese adults. J. Epidemiol. 2012, 22, 151-159. [CrossRef] [PubMed]

15. Kobayashi, S.; Murakami, K.; Sasaki, S.; Okubo, H.; Hirota, N.; Notsu, A.; Fukui, M.; Date, C. Comparison of relative validity of food group intakes estimated by comprehensive and brief-type self-administered diet history questionnaires against $16 \mathrm{~d}$ dietary records in Japanese adults. Public Health Nutr. 2011, 14, 1200-1211. [CrossRef]

16. Munakata, M. Brachial-ankle pulse wave velocity in the measurement of arterial stiffness: Recent evidence and clinical applications. Curr. Hypertens. Rev. 2014, 10, 49-57. [CrossRef]

17. Arnett, D.K.; Blumenthal, R.S.; Albert, M.A.; Buroker, A.B.; Goldberger, Z.D.; Hahn, E.J.; Himmelfarb, C.D.; Khera, A.; Lloyd-Jones, D.; McEvoy, J.W.; et al. ACC/AHA Guideline on the Primary Prevention of Cardiovascular Disease: Executive Summary: A Report of the American College of Cardiology/American Heart Association Task Force on Clinical Practice Guidelines. J. Am. Coll. Cardiol. 2019, 74, 1376-1414. [CrossRef]

18. Yamashina, A. Guidelines for Non-Invasive Vascular Function Test; JCS Publishing: Gloucestershire, UK, 2013. 
19. Committee to Evaluate Diagnostic Standards for Metabolic Syndrome. The definition and Diagnostic Criteia of Metabolic Syndrome. Nihon Naika Gakkai Zasshi. 2005, 94, 188-203. [CrossRef]

20. Montarroyos, U.R.; Miranda-Filho, D.B.; Cesar, C.C.; Souza, W.V.; Lacerda, H.R.; Albuquerque Mde, F.; Aguiar, M.F.; Ximenes, R.A Factors related to changes in CD4+ T-cell counts over time in patients living with HIV/AIDS: A multilevel analysis. PLoS ONE 2014, 9, e84276. [CrossRef]

21. He, L.; Pan, X.; Dou, Z.; Huang, P.; Zhou, X.; Peng, Z.; Zheng, J.; Zhang, J.; Yang, J.; Xu, Y.; et al. The Factors Related to CD4+ T-Cell Recovery and Viral Suppression in Patients Who Have Low CD4+ T Cell Counts at the Initiation of HAART: A Retrospective Study of the National HIV Treatment Sub-Database of Zhejiang Province, China, 2014. PLoS ONE 2016, 11, e0148915. [CrossRef]

22. Means, A.R.; Risher, K.A.; Ujeneza, E.L.; Maposa, I.; Nondi, J.; Bellan, S.E. Impact of Age and Sex on CD4+ Cell Count Trajectories following Treatment Initiation: An Analysis of the Tanzanian HIV Treatment Database. PLoS ONE 2016, 11, e0164148. [CrossRef]

23. Lifson, A.R.; Krantz, E.M.; Eberly, L.E.; Dolan, M.J.; Marconi, V.C.; Weintrob, A.C.; Crum-Cianflone, N.F.; Ganesan, A.; Grambsch, P.L.; Agan, B.K. Long-term CD4+ lymphocyte response following HAART initiation in a U.S. Military prospective cohort. AIDS Res. Ther. 2011, 8, 2. [CrossRef]

24. Koethe, J.R.; Jenkins, C.A.; Shepherd, B.E.; Stinnette, S.E.; Sterling, T.R. An optimal body mass index range associated with improved immune reconstitution among HIV-infected adults initiating antiretroviral therapy. Clin. Infect. Dis. 2011, 53, 952-960. [CrossRef]

25. Johnson, K.D.; Cai, B.; Duffus, W.; White, K.; Smieja, M.; Divya, A.; Merchant, A.T. Longitudinal association between BMI at diagnosis and HIV disease progression. AIDS Behav. 2014, 18, 2249-2257. [CrossRef] [PubMed]

26. Velloso, L.A.; Savino, W.; Mansour, E. Leptin action in the thymus. Ann. N. Y. Acad. Sci. 2009, 1153, 29-34. [CrossRef] [PubMed]

27. Kim, S.Y.; Lim, J.H.; Choi, S.W.; Kim, M.; Kim, S.T.; Kim, M.S.; Cho, Y.S.; Chun, E.; Lee, K.Y. Preferential effects of leptin on CD4 T cells in central and peripheral immune system are critically linked to the expression of leptin receptor. Biochem. Biophys. Res. Commun. 2010, 394, 562-568. [CrossRef] [PubMed]

28. Cobos Jiménez, V.; Wit, F.W.; Joerink, M.; Maurer, I.; Harskamp, A.M.; Schouten, J.; Prins, M.; van Leeuwen, E.M.; Booiman, T.; Deeks, S.G.; et al. T-Cell Activation Independently Associates with Immune Senescence in HIV-Infected Recipients of Long-term Antiretroviral Treatment. J. Infect. Dis. 2016, 214, 216-225. [CrossRef]

29. Gutierrez, J.; Albuquerque, A.L.A.; Falzon, L. HIV infection as vascular risk: A systematic review of the literature and metaanalysis. PLoS ONE 2017, 12, e0176686. [CrossRef]

30. Benjamin, L.A.; Allain, T.J.; Mzinganjira, H.; Connor, M.D.; Smith, C.; Lucas, S.; Joekes, E.; Kampondeni, S.; Chetcuti, K.; Turnbull, I.; et al. The Role of Human Immunodeficiency Virus-Associated Vasculopathy in the Etiology of Stroke. J. Infect. Dis. 2017, 216, 545-553. [CrossRef]

31. Hiroshige, K.; Tominaga, M.; Hiyoshi, E.; Fukuda, R. Examination of Body Composition Analysis Factors Influencing Branchialankle Pulse Wave Velocity in Workers. JJOMT 2012, 60, 289-294.

32. Kagawa, M.; Kerr, D.; Uchida, H.; Binns, C.W. Differences in the relationship between BMI and percentage body fat between Japanese and Australian-Caucasian young men. Br. J. Nutr. 2006, 95, 1002-1007. [CrossRef] [PubMed]

33. Deurenberg, P.; Deurenberg-Yap, M.; Guricci, S. Asians are different from Caucasians and from each other in their body mass index/body fat per cent relationship. Obes Rev. 2002, 3, 141-146. [CrossRef] [PubMed]

34. Soares, L.R.; da Silva, D.C.; Gonsalez, C.R.; Batista, F.G.; Fonseca, L.A.M.; Duarte, A.J.S.; Casseb, J. Discordance between body mass index and anthropometric measurements among HIV-1-infected patients on antiretroviral therapy and with lipoatrophy/lipohypertrophy syndrome. Rev. Inst. Med. Trop. Sao Paulo 2015, 57, 105-110. [CrossRef] [PubMed]

35. The Ministry of Health, Labor and Welfare the AIDS Outbreak Trends Survey. 2020. Available online: https://api-net.jfap.or.jp/ status/japan/nenpo.html (accessed on 20 December 2021). 